\title{
Ускладнення та небажані явища під час операціі артропластики кульшового суглоба в умовах регіонарної анестезіi
}

\section{В. І. Коломаченко}

Харківська медична академія післядипломної освіти, Харківська обласна клінічна травматологічна лікарня

\section{Complications and unwanted events during operation of arthroplasty of a hip joint in conditions of regional anesthesia}

\author{
V. I. Kolomachenko \\ Kharkiv Medical Academy of Postgraduate Education, \\ Kharkiv Regional Clinical Traumatological Hospital
}

\section{Реферат}

Мета. Аналіз ускладнень і небажаних ефектів регіонарної анестезії під час артропластики кульшового суглоба. Матеріали і методи. У 346 пацієнтів, яким виконали артропластику кульшового суглоба в умовах різних методів регіонарної анестезії, проаналізували інтраопераційні побічні ефекти та небажані явища. Середній вік паціентів становив $(63,17 \pm 12,26)$ року.

Результати. Найбілыше часу потребувало виконання каудальної блокади з паравертебральною катетеризацією - (12 $\pm 2)$ хв. Ненавмисну пункцію судин фіксували під час виконання блокад нервів (7\% спостережень) та каудальної блокади з паравертебральною блокадою (6\%). Потреба зміни спрямування голки найчастіше виникала під час виконання псоас-компартмент блоку (22\% спостережень) та каудальної блокади (19\%). Недостатньою аналгезія найчастіше була у пацієнтів, яким застосовували блокаду нервів (22\%). Додаткове введення опіоїдів призводило до пригнічення дихання у 16\% пацієнтів даної групи. Порушення гемодинаміки (аритмія та гіпотензія) найчастіше виникали у пацієнтів, яким застосовували спінальну анестезію. Усі групи пацієнтів не різнилися статистично значущо за частотою нудоти та блювання, а також тремтіння.

Висновки. Блокади периферичних нервів за впливом на гемодинаміку пацієнта є безпечнішими у порівнянні 3 нейраксіальними. Водночас вони менш ефективні та більш трудомісткі.

ключові слова: артропластика кульшового суглоба; регіонарна анестезія; ускладнення.

\section{Abstract}

Objective. Analysis of complications and effects of regional anesthesia while doing arthroplasty of a hip joint.

Materials and methods. In 346 patients, in whom arthroplasty of a hip joint was performed in conditions of various methods of regional anesthesia,intraoperative unwanted effects and events were analyzed. Middle age of the patients have constituted $(63.17 \pm 12.26)$ yrs old.

Results. Most time-consuming procedure have appeared a performance of caudal blockade with paravertebral catheterization - (12 \pm 2$) \mathrm{min}$. Incidental puncture of vessels was registered while doing the nerves blockade (7\% of observations) and caudal blockade with paravertebral blockade (6\%). Necessity to change the needle marsh rut have occurred while performance of a psoas-compartment block (22\% of observations) and caudal blockade (19\%). Analgesia have appeared insufficient most frequently in patients, in whom the nerves blockade was performed (22\%). Additional administration of opioids have leaded to the respiration inhibition in 16\% patients of this group. Disorders of hemodynamics (arrhythmia and hypotension) most frequently have occurred in patients, in whom spinal anesthesia was applied. All groups of the patients did not differ statistically significantly in aspects of rate of nausea and vomiting, as well as tremor.

Conclusion. Blockades of peripheral nerves in aspect of hemodynamics in the patient is safer, than a neuraxial one. They are also less effective and more laborious.

Keywords: arthroplasty of a hip joint; regional anesthesia; complications.

Ендопротезування кульшового суглоба (КС) є однією з найпоширеніших операцій у сучасній ортопедії [1] Виходячи з об'єму цього оперативного втручання, методи знеболювання мусять задовольняти такі вимоги: адекватний захист від операційної травми та можливість надійного зниження інтенсивності післяопераційного болю для забезпечення ранньої мобілізації [2]. Окрім того, похилий вік і супутні захворювання пацієнтів породжують додаткові ризики [3]. Регіонарні блокади як самостійне знеболювання або компонент комбінованої анестезії мають низку переваг у таких пацієнтів, але оптимальний метод досі не визначений, у тому числі з точки зору безпеки та частоти виникнення ускладнень $[4,5]$.

Мета дослідження: порівняти частоту розвитку небажаних явищ та ускладнень під час артропластики КС в умовах регіонарної анестезії.

\section{Матеріали і методи дослідження}

Дослідження, до якого було включено 347 пацієнтів (205 жінок та 142 чоловіки) віком від 24 до 95 років, яким вико- 


\begin{tabular}{|c|c|c|c|c|c|c|}
\hline \multirow[t]{2}{*}{ Група } & \multirow[t]{2}{*}{ Число хворих } & \multicolumn{2}{|c|}{ Метод } & \multirow{2}{*}{$\begin{array}{c}\text { Вік, років } \\
(\bar{x} \pm \sigma)\end{array}$} & \multicolumn{2}{|c|}{ Стать } \\
\hline & & IO анестезії & ПО аналгезії & & 4 & ж \\
\hline I & 78 & $\mathrm{CA}$ & Опіоїди в/м & $62,6 \pm 12,0$ & 31 & 47 \\
\hline II & 69 & $\mathrm{CA}+$ ПВБ & ПВБ (продовжена) & $62,5 \pm 12,5$ & 29 & 40 \\
\hline III & 68 & CEA & ЕА (продовжена) & $62,8 \pm 13,0$ & 26 & 42 \\
\hline IV & 69 & ПКБ + БСН (одноразова) & Опіоїди в/м & $59,8 \pm 14,3$ & 30 & 39 \\
\hline V & 63 & $\Pi B Б+K A$ & ПВБ (продовжений) & $62,6 \pm 12,2$ & 26 & 37 \\
\hline Примітка. & \multicolumn{6}{|c|}{$\begin{array}{l}\text { СА - спінальна анестезія; ПВБ - паравертебральна блокада; СЕА - спінально-епідуральна анестезія; } \\
\text { ЕА - епідуральна анестезія; ПКБ - псоас-компартмент блок; БСН - блокада сідничного нерва; КА - каудальна } \\
\text { анестезія; в/М - внутрішньом'язово }\end{array}$} \\
\hline
\end{tabular}

нали ендопротезування КС, проведене у Харківській обласній клінічній травматологічній лікарні у 2012 - 2017 pp. Середній вік пацієнтів становив $(63,17 \pm 12,26)$ року. На проведення дослідження отримано дозвіл етичного комітету Харківської медичної академії післядипломної освіти (протокол засідання № 5 від 2012 р.). Критерії включення хворих до дослідження: планове первинне ендопротезування КС, фізичний статус, оцінений за класифікацією Американського союзу анестезіологів як ASA II ASA III, інформована згода на застосування анестезії та на участь у дослідженні. Після включення до дослідження пацієнтів рандомізували на п'ять груп у залежності від методу інтраопераційної (IO) анестезії та післяопераційної (ПО) аналгезії шляхом генерації випадкових чисел від 1 до 5 у програмному забезпеченні Microsoft Excel 2013 (Microsoft Corporation, США) за допомогою функції СЛУЧМЕЖДУ(1;5). Генероване випадкове число відповідало групі, до якої включали пацієнта. Статистично значущої різниці між групами за демографічними показниками не було (табл. 1).

Протокол анестезї/аналгезїу групі I. Спінальну анестезію виконували на рівні L3 - L4 парамедіанним доступом у положенні пацієнта на здоровому боці спінальною голкою Квінке (G26, Spinocan, B. BraunMelsungen AG, Melsungen, Німеччина). Інтратекально вводили 12 мг (2,4 мл) 0,5\% розчину бупівакаїну. Для післяопераційного знеболювання використовували опіоїди, які вводили внутрішньом'язово, якщо інтенсивність болю перевищувала 4 бали за візуально-аналоговою шкалою (ВАШ).

Протокол анестезіі/аналгезїу групі II. Спінальну анестезію виконували, як у групі І. Після цього виконували катетеризацію паравертебрального простору на рівні L3 на стороні операції (ідентифікація за тестом втрати опору) із застосуванням набору для епідуральної анестезії (G18, Perifix 401, B.BraunMelsungen AG, Melsungen, Німеччина) та вводили 20 мл 1\% розчину лідокаїну. У післяопераційному періоді продовжували інфузію 0,25\% розчину бупівакаїну в паравертебральний простір у темпі 3 мл/год.

Протокол анестезї/аналгезї̈ групі III. Спінальноепідуральну анестезію виконували на рівні L3 - L4 у положенні хворого на здоровому боці (ідентифікація за тестом втрати опору) з використанням набору для комбінованої спінально-епідуральної анестезії (G18, Espocan, B. BraunMelsungen AG, Melsungen, Німеччина).
Інтратекально вводили 12 мг (2,4 мл) 0,5\% розчину бупівакаїну. Епідуральний катетер проводили на 3 - 4 см краніально. Після операції продовжували інфузію 0,125\% розчину бупівакаїну в епідуральний катетер у темпі 3 мл/год.

Протокол анестезї/аналгезї̈у групі IV. Одноразова блокада поперекового сплетення заднім доступом у положенні хворого на здоровому боці (псоас-компартмент блок за Capdevila) з використанням ізольованої голки для нейростимуляції (G21, Stimuplex A, 100 mm, B. BraunMelsungen AG, Melsungen, Німеччина) та нейростимулятора (Stimuplex HNS-12, B. BraunMelsungen AG, Melsungen, Німеччина). Після цього в такому ж положенні хворого виконували блокаду сідничного нерва за аналогічною методикою Labat-Moore. У поперекове сплетення та сідничний нерв вводили по 400 мг (40 мл) 1\% розчину лідокаїну з додаванням адреналіну (в розведенні 1:200000) та дексаметазону (по 2 мг). Для післяопераційного знеболювання використовували опіоїди, які вводили внутрішньом'язово, якщо інтенсивність болю перевищувала 4 бали за ВАШ.

Протокол анестезіі/аналгезїу групі V. Одноразова блокада поперекового сплетення заднім доступом із наступною катетеризацією паравертебрального простору на рівні L3 на стороні операції (ідентифікація за тестом втрати опору) із застосуванням набору для епідуральної анестезії (G18, Perifix 401, B. Braun Melsungen AG, Melsungen, Німеччина). В паравертебральний простір вводили 30 мл 1\% розчину лідокаїну. Далі виконували каудальну анестезію сліпою методикою (ідентифікація за тестом втрати опору). В епідуральний простір каудальним доступом вводили 20 мл 0,75\% розчину ропівакаїну. Для післяопераційного знеболювання продовжували інфузію 0,25\% розчину бупівакаїну в катетер у просторі поперекового м'яза в темпі 3 мл/год.

У всіх пацієнтів як компоненти мультимодальної аналгезії застосовували парацетамол, нестероїдний протизапальний засіб та інфільтрацію шкіри і параартикулярних тканин місцевим анестетиком низької концентрації.

Небажані явища та ускладнення реєстрували безпосередньо під час виконання блокади та в інтраопераційному періоді. Небажаним явищем вважали будь-яку несприятливу зміну у стані здоров'я пацієнта, який отримував регіонарну анестезію, незалежно від причинного зв'язку з цією інтервенцією. Ускладненням вважали небажане явище, 
яке мало причинний зв’язок з інтервенцією [6]. Крім цього, реєстрували технічні труднощі виконання тої чи іншої методики анестезіі/аналгезії та задоволеність пацієнтів перебігом інтраопераційного періоду за п'ятибальною шкалою, час, витрачений на виконання блокади, а також кількість пацієнтів, що потребували додаткового знеболювання.

Депресію дихання реєстрували, коли відмічали брадипное, падіння показника насичення крові киснем $\left(\mathrm{SpO}_{2}\right)$ до 90\% та нижче, необхідність оксигенотерапії, обструкцію верхніх дихальних шляхів, яка потребувала втручання: підтримання прохідності дихальних шляхів за допомогою виведення щелепи або за допомогою пристроїв [7]. Артеріальною гіпотензією вважали падіння систолічного артеріального тиску (АТ сист.) нижче 90 мм рт. ст. або середнього артеріального тиску (АТ серед. $_{\text {. }}$ нижче 60 мм рт. ст., або зниження АТ сист. та/або АТ базового рівня [8]. В інших спостереженнях реєстрували кількість епізодів небажаних явищ або ускладнень.

Статистичне опрацювання даних здійснено в програмі STATISTICA 8.0 (StatSoftInc., Tulsa, США). Значущість різниці між групами за кількістю епізодів небажаних явищ та ускладнень обчислювали за допомогою точного критерію Фішера та представляли у вигляді величини р. Загальна кількість ускладнень та небажаних явищ у групах представлена в абсолютних числах та відсотках. Щодо часу, витраченого на виконання блоку, та суб'єктивних оцінок пацієнтами задоволеності перебігом інтраопераційного періоду обчислювали середні значення (М) та стандартні відхилення $(\sigma)$ величин, а значущість різниці середніх значень між групами оцінювали за допомогою неспарованого двобічного критерію Ст’юдента, різницю вважали значущою, коли значення р було менше 0,05. Результати наведені у вигляді: середне значення \pm стандартне відхилення $(\mathrm{M} \pm \sigma)$.

\section{Результати}

Частота небажаних явищ та ускладнень у групах була різною (табл.2).

Пункцію судини з аспірацією крові у пацієнтів групи I не відмічали, а у пацієнтів груп IV та V частота цього ускладнення була більшою, ніж у пацієнтів груп II та III, що зумовлено необхідністю більш чіткої ідентифікації гілок поперекового сплетення, розташованого в товщі великого поперекового м'яза, у разі виконання псоас-компартмент блоку та довшим просуванням голки по добре васкуляризованому епідуральному простору у разі виконання каудальної блокади.

Не вдавалося виконати блокаду з першої спроби у пацієнтів усіх груп. Потреба введення голки в іншому напрямку найбільш часто виникала під час виконання псоас-ком-

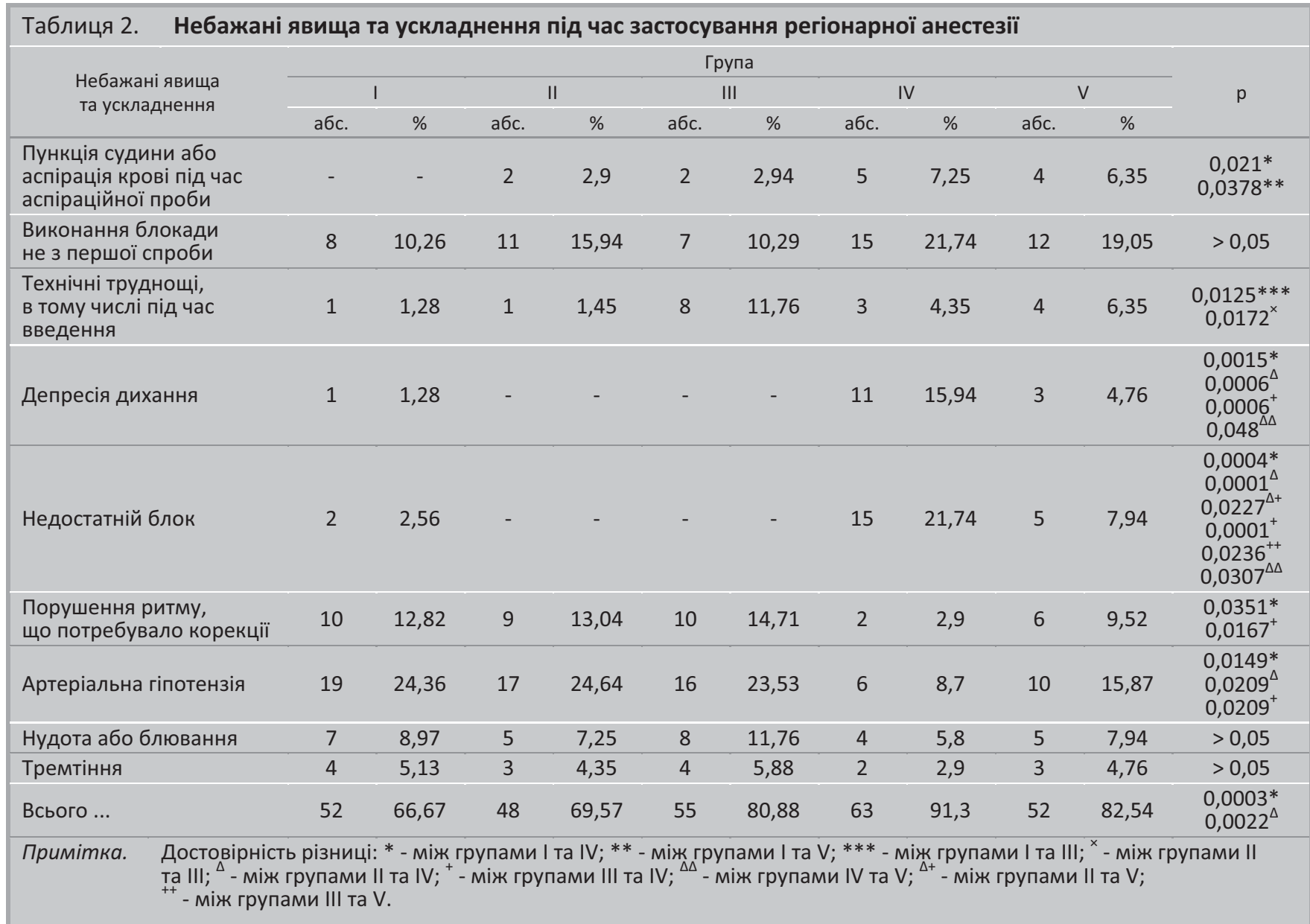




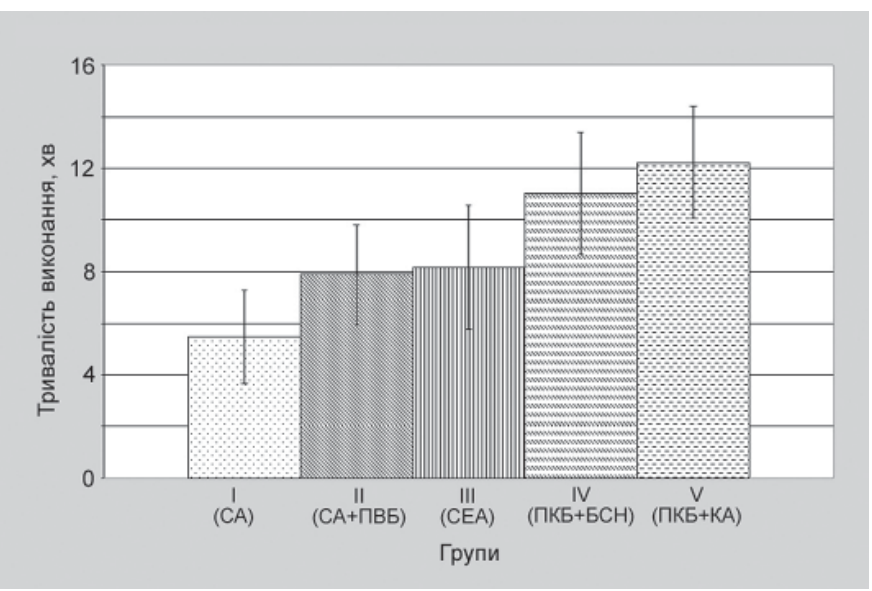

PUc. 1.

Тривалість виконання регіонарних блоків.

партмент блоку у пацієнтів групи IV та під час виконання каудальної блокади у пацієнтів групи V, хоча різниця між групами за цим показником не була статистично значущою. Але це зовсім не означає, що ці блокади технічно були найбільш складними. Найбільше технічних складнощів виникало під час проведення спінально-епідуральної анестезії у пацієнтів групи III, що зумовлено необхідністю потрапити більш товстою голкою у вузьке вікно міждужкового проміжку та ввести катетер в епідуральний простір без попередньої його гідропрепаровки місцевим анестетиком, що викликає парестезії під час введення катетера та підвищує ймовірність його міграції. Статистично значущою різниця за цим показником була між пацієнтами групи III та пацієнтами груп I та II. Слід зауважити, що у пацієнтів групи II виконували катетеризацію паравертебрального простору на поперековому рівні, яка практично ніколи не буває проблемною. Складнощі виникли лише у 1 (1,45\%) пацієнта з надмірною масою тіла, коли потрібно було використати більш довгу голку.

Недостатній рівень аналгезії найбілыш часто спостерігали у пацієнтів групи IV (периферичні блоки), що зумовлено складною іннервацією КС та особливостями розташування поперекового сплетення і розповсюдження анестетика після його введення до псоас-компартменту. За цим показником пацієнти групи IV мали статистично значущу відмінність від пацієнтів груп I, II, III та V. Після вдосконалення методики Capdevila [9] кількість пацієнтів, у яких було неадекватне знеболювання, значно зменшилась. Недостатній рівень блоку спостерігали у 5 (7,94\%) пацієнтів групи V, що мало статистично значущу відмінність у порівнянні з пацієнтами груп II та III та вказувало на потребу більш ретельного ставлення до ідентифікації епідурального простору під час виконання каудальної блокади.

Через больові відчуття додатково вводили аналгетики і гіпнотики, що призвело до депресії дихання у 11 (15,94\%) пацієнтів групи IV. За цим показником група IV статистично значущо відрізнялась від решти груп.

Гемодинамічні порушення найчастіше спричиняла спінальна анестезія, тому пацієнти груп I, II та III статистично значущо відрізнялись від пацієнтів, у яких застосову-

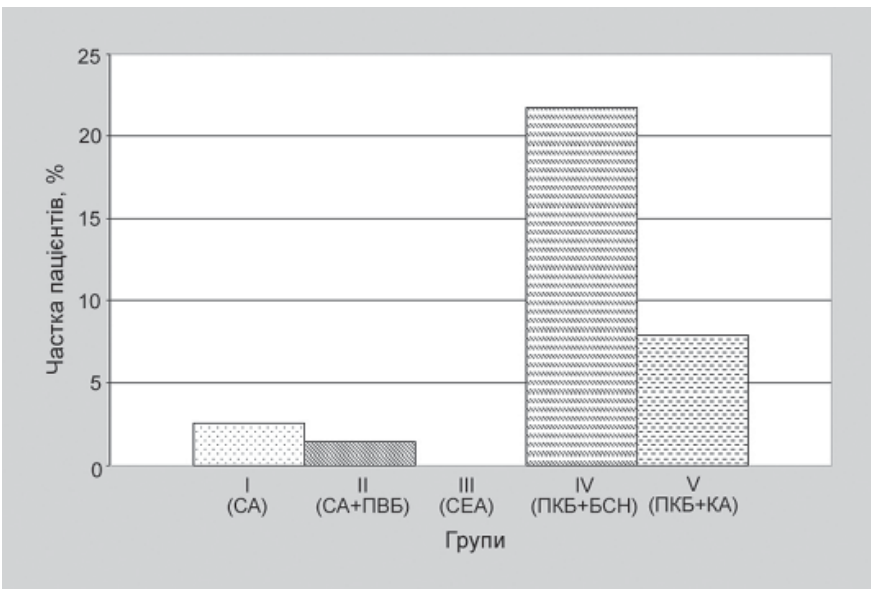

Рис. 2. Частка пащієнтів, що потребували додаткового інтраопераційного знеболювання.

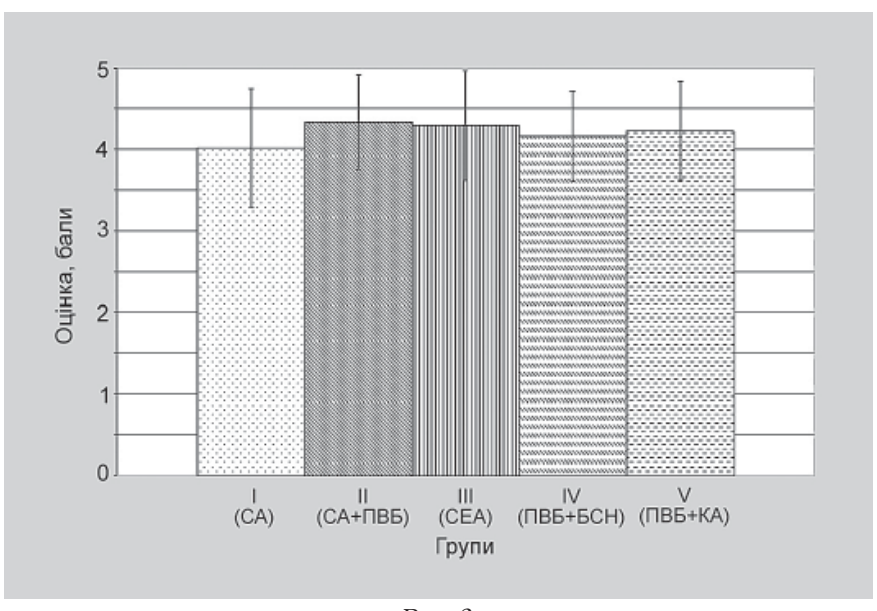

Puc.3.

Суб'єктивна оцінка пацієнтами якості анестезї.

вали периферичні блоки, як за частотою порушень ритму, так і за частотою гіпотензіі.

За частотою виникнення нудоти та блювання, а також тремтіння групи I, II, III, IV та V статистично значущо не відрізнялись між собою. Ми не спостерігали у досліджуваних пацієнтів інших описаних у літературі загрозливих небажаних явищ та ускладнень з боку нервової системи (судоми, неврологічний дефіцит внаслідок пошкодження нервових структур), а також системної токсичності місцевих анестетиків.

За сумарною кількістю небажаних явищ та ускладнень групи клінічно суттєво не відрізнялися між собою, проте найбільшою вона була у пацієнтів групи IV - 63 (91,3\%), оперованих в умовах периферичних блокад, та статистично значущо відрізнялася від відповідного показника у пацієнтів груп I та II.

Виконання регіонарної анестезії, тим більше з катетеризацією, потребує часу, особливо це стосується периферичних блоків нижньої кінцівки, що зумовлено необхідністю окремих ін'єкцій для блокади гілок поперекового та крижового сплетень (рис. 1).

Найбільше часу витрачали на виконання каудальної блокади в поєднанні з катетеризацією паравертебраль- 
ного простору на поперековому рівні - $(12,22 \pm 2,19)$ хв, що зумовлено складністю даної маніпуляції у дорослих, до того ж ми приділяли велику увагу належній верифікації епідурального простору. За цим показником пацієнти групи V статистично значущо відрізнялися від пацієнтів решти груп ( $\mathrm{p}=0,0001)$.

Найбільше пацієнтів потребували додаткового знеболювання опіоїдами під час операції (рuс. 2) у групі IV (периферичні блокади нервів) - 15 (21,74\%). За цим показником група IV статистично значущо відрізнялася від групи I (p=0,0003), групи II (p=0,0002), групи III (p=0,0001) та групи V ( $\mathrm{p}=0,0195)$. Варто зауважити, що больові відчуття найчастіше виникали під час обробки каналу стегнової кістки римерами, а не під час роботи на вертлюжній впадині, як цього можна було б очікувати.

Хоч для анестезіолога виконання блокади периферичних нервів або їх комбінацій з нейраксіальними методами є більш складним та потребує більше часу, пацієнти мали високий рівень задоволення ними без статистично значущої різниці між групами (рис. 3).

\section{Обговорення}

Обрання оптимального методу анестезії для ендопротезування КС досі лишається предметом дискусій [2]. Низкою досліджень $[4,5]$ доведено переваги нейраксіальної анестезії перед загальною. Разом з тим є повідомлення про вищий ризик тромбоемболії після спінальної анестезії [10]. Блокади периферичних нервів, за даними літератури, мають переваги і над загальною, і над нейраксіальною анестезією [11], однак і вони не позбавлені ризику виникнення специфічних ускладнень [12].

Отримані нами результати свідчать про низку переваг блокад периферичних нервів щодо інтраопераційних небажаних явищ, але ці методи анестезії потребують більше часу та професійності для виконання. До того ж, за неповної аналгезії потреба додаткового введення опіоїдів та аналгетиків може спричинити депресію дихання.

\section{Висновки}

Серед досліджених методів регіонарної анестезії блокади периферичних нервів за впливом на гемодинаміку пацієнта є безпечнішими, ніж нейраксіальні, хоча вони менш ефективні та більш трудомісткі.

\section{Підтвердження}

Фінансування. За власний рахунок.

Конфлікт інтересів. Автор декларує відсутність конфлікту інтересів.

\section{References}

1. Learmonth ID, Young C, Rorabeck C. The operation of the century: total hip replacement. Lancet. 2007 Oct;370(9597):1508-19. doi: 10.1016/ S0140-6736(07)60457-7.

2. Cowan R, Lim JH, Ong T, Kumar A, Sahota O. The challenges of anaesthesia and pain relief in hip fracture care. Drugs Aging. 2017 Jan; 34(1):1-11. doi: 10.1007/s40266-016-0427-5. doi: 10.1007/s40266016-0427-5.

3. Taheriazam A, Saeidinia A, Keihanian F. Total hip arthroplasty and cardiovascular complications: a review. TherClin Risk Manag. 2018 Apr 13;14:685-90. doi: 10.2147/TCRM.S155918.

4. Johnson RL, Kopp SL, Burkle CM, Duncan CM, Jacob AK, Erwin PJ, et al. Neuraxial vs general anaesthesia for total hip and total knee arthroplasty: a systematic review of comparative-effectiveness research. $\mathrm{Br} \mathrm{J}$ Anaesth. 2016 Feb;116(2):163-76. doi: 10.1093/bja/aev455.

5. Liang C, Wei J, Cai X, Lin W, Fan Y, Yang F. Efficacy and safety of 3 different anesthesia techniques used in total hip arthroplasty. Med Sci Monit. 2017 Aug 2;23:3752-9. doi: 10.12659/MSM.902768.

6. Oganova RG, editor Osnovy dokazatelnoj mediciny. Uchebnoe posobie dlja sistemy poslevuzovskogo i dopolnitel'nogo professional'nogo obrazovanija vrachej. Moskva: Siliceja-Poligraf; 2010. $136 \mathrm{~s}$.

7. Ko S, Goldstein DH, Van Den Kerkhof EG. Definitions of "respiratory depression" with intrathecal morphine postoperative analgesia: a review of the literature. Can J Anaesth. 2003 Aug-Sep;50(7):679-88. doi: 10.1007/BF03018710.

8. Bijker JB, van Klei WA, Kappen TH, van Wolfswinkel L, Moons KG, Kalkman CJ. Incidence of intraoperative hypotension as a function of the chosen definition: Literature definitions applied to a retrospective cohort using automated data collection. Anesthesiology 2007 Aug; 107(2):21320. doi: 10.1097/01.anes.0000270724.40897.8e.

9. Kryvobok VI, Chaplynskyi RP, Kolomachenko VI, Fesenko VS, vynakhidnyky; Kharkivska medichna akademiia gssliadiplomnoi osvity, patentovlasnyk. Sposib provedennia providnykovoi anestezii kulshovoho suhloba. Patent Ukainy No 60765. 2011 cher 25. [In Ukrainian].

10. Nakamura M, Kamei M, Bito S, Migita K, Miyata S, Kumagai K, et al. Spinal anesthesia increases the risk of venous thromboembolism in total arthroplasty: Secondary analysis of a J-PSVT cohort study on anesthesia. Medicine (Baltimore). 2017 May;96(18):e6748. doi: 10.1097/ MD.0000000000006748.

11. Guay J, Parker MJ, Griffiths R, Kopp S. Peripheral nerve blocks for hip fractures. Cochrane Database Syst Rev. 2017 May 11;5:CD001159. doi: 10.1213/ANE.0000000000002489.

12. Lee BH, Braehler M. Use of test dose allows early detection of subdural local anesthetic injection with lumbar plexus block. J Clin Anesth. 2017 Feb;37:111-3. doi: 10.1016/j.jclinane.2016.11.011. 